\title{
Electricity Consumption in Manufactured Housing
}

Address: $\quad$ Professor Sanford V. Berg

Department of Economics

University of Florida

Gainesville, FL 32611

Telephone: $\quad$ (904) 392-0132

FAX: $\quad$ (904) $392-3905$ 


\title{
Electricity Consumption in Manufactured Housing
}

\author{
by Sanford V. Berg and Christopher Taylor*
}

March 8, 1991

\begin{abstract}
This paper presents empirical results regarding the determinants of electricity consumption in manufactured housing, commonly called mobile homes. The data consist of a random sample of over 400 Florida electricity customers--with information on socioeconomic characteristics, housing features, and monthly $K W H$ consumption. The model explains over forty percent of the variation among customer usage, with signs and sizes of various coefficients fitting economic theory. The results for thermostat settings, site orientation, and conservation investments are particularly interesting.
\end{abstract}

* Berg is the Florida Public Utilities Professor, University of Florida. Taylor was a Research Associate at the Public Utility Research Center (PURC) when this study was completed. He is currently a graduate student at Clemson University. This research was supported by grants from the Florida Governor's Energy Office and PURC. The conclusions do not necessarily reflect the views of sponsoring organizations.

Keywords: electricity consumption, manufactured housing, site orientation

Abbreviated title: Electricity in Manufactured Housing 


\section{Electricity Consumption in Manufactured Housing by Sanford V. Berg and Christopher Taylor}

Manufactured houses, commonly called mobile homes, represent a significant portion of the national housing stock for some regions of the United States. They also offer much potential for developing nations, insofar as the advantages of mass production can lower the cost of basic housing. The energy efficiency of such housing is lower than in site-built homes for a number of reasons noted below. Previous residential cross-section studies have focused on site-built homes, which comprise the vast majority of units. However, for some states, manufactured homes constitute a significant and growing portion of the total. In the case of Florida, nearly ten percent of residential electricity connections are to manufactured homes. In some counties, such homes represent over half of the new hook-ups each year (Capehart, et. al. 1989). Thus, system planners and energy analysts need to understand the determinants of this component of residential electricity consumption.

This study is divided into four sections: (1) an overview of manufactured housing characteristics, including ownership and electricity consumption; (2) theory of electricity consumption and model specification; (3) empirical tests of both a basic and more comprehensive electricity consumption model; and (4) energy policy implications.

\section{OVERVIEW OF MANUFACTURED HOUSING}

The lifestyle associated with manufactured housing can take a number of forms: clusters of tightly packed "trailers" occupied by students, low income retirees and young blue collar families; single and double-wides situated on spacious rural sites; or developments with relatively elegant "coaches" lining well-maintained streets and sharing access to state-of-the-art security and recreation services. Patterns of energy consumption will differ across these groupings, although they will still have much in common. Even with the same climate, the level and pattern of consumption differ from 
those of families living in single family site-built dwellings.

Florida, the fourth-largest state in the U.S., has a relatively high proportion of manufactured homes. The U.S. Department of Housing and Urban Development (HUD) energy standards for such residences are far lower than those mandated for site-built homes: HUD sets only heating standards, although the demand for cooling is also very important in Florida. The R-11-7-7 insulation levels in the ceiling, walls, and floor have not changed since 1976. Furthermore, HUD energy standards for manufactured homes preclude more stringent state-mandated standards. Site-built homes which meet the current Florida Model Building Code have insulation levels of R-38-19 in the ceiling and the walls.

Since manufactured houses are designed for affordability, relatively low thermal envelope standards need not imply inadequate investment in conservation. However, there is evidence that greater factory-installed insulation has a relatively short pay-back period. For example, Capehart, et. al. (1990) find that upgrading from the minimum HUD standards to R-28-11-19 costs $\$ 414$. The reduced electric bills yield a payback period of less than three years.

Economic savings from retrofits are more problematic, but exist for some conservation investments. Our data, which were derived from a Florida Public Service Commission (FPSC) sample of residential housing, indicate that 43 percent of the manufactured housing units selected at random were 13 or more years old in 1985 . Clearly, the stock of older units raises some difficult issues. An earlier HUD study (Mobile Home Research, Thermal Envelope Systems, October 1979) used infrared thermographic analysis to locate thermal leaks in the external structural elements of a single-wide and double-wide manufactured home. Investigators then disassembled the wall, ceiling, and floor areas to determine the causes of thermal leaks. Inappropriate installation of insulation (including compression of material by wiring within the walls and ceilings) and poor or non-existent sealant application were responsible for significant preventable thermal inefficiencies. Improvements in 
design and set-up procedures (such as duct work) were also identified as areas warranting attention.

In order to demonstrate the cost-effectiveness of various conservation investments for new housing, actual electricity consumption can be compared across customers with different housing and appliance characteristics. Engineering models may be able to give fairly precise calculations of potential savings; however, behavioral adjustments by customers can yield actual energy savings which differ from those predicted from simulations. For example, at a constant electricity price, additional insulation reduces the cost of comfort faced by the consumer. The lower real price of comfort means that engineering estimates will overpredict the energy savings since consumers will tend to purchase more comfort (and thus more $\mathrm{KWH}$ ).

\section{THEORY OF ELECTRICITY CONSUMPTION AND MODEL SPECIFICATION}

The literature on the determinants of electricity consumption is vast. The NIECS data base has provided useful disaggregated data for the study of variations in household KWH usage. For example, Hirst, Goeltz and Carney (1982) found that the demand for comfort was a major determinant of monthly consumption: the key variable was the product of heating degree days and floor area (a proxy for energy needed to heat the residence). The elasticity with respect to this heating factor was about 0.3 . Family size, income, and age of home were also significant determinants of consumption. Garbacz (1983) excluded dwelling size, focusing on an index of appliance stock. Others have examined auxiliary heating (Reilly and Shankle, 1988), preferred thermostat settings (Kushman and Anderson, 1986), and continuous occupancy (Capper and Scott, 1982). The latter study found that each additional degree centigrade increased electricity consumption by 3 percent for homes in the United Kingdom.

The presence or absence of particular appliances has also been used in models of electricity consumption. For example, Parti and Parti (1980) use zero-one dummies and interaction terms to determine the KWH consumption associated with ownership of individual appliances. Such 
conditional demand analyses have been surveyed in two Electric Power Research Institute (EPRI) studies $(1984,1988)$ and are regularly conducted by electric utilities since the metering costs for alternative approaches (such as appliance-specific studies) can be very high.

To place the analysis in perspective, it is useful to have an understanding of the baseline conditions for the manufactured housing population. The only relatively comprehensive sample of which we are aware, is the Florida Public Service Commission 1986 Customer Survey: of the 5,922 households in the sample, 688 have manufactured homes. Because of data omissions, the sample utilized in the actual regression is somewhat smaller. Nevertheless, it enables a comprehensive analysis of the determinants of electricity consumption by these households. Table 1 presents some statistics for the sample. Not until the 1990 census is available will there be a comprehensive sample with such housing detail (although without energy consumption information).

\section{EMPIRICAL TESTS AND ECONOMIC INTERPRETATION}

\subsection{A Basic Model}

Monthly models were estimated to obtain information on the stability of coefficients. The billing cycle in the data base spans the period from March 1985 through February 1986. Due to significant problems with the accuracy and completeness of the raw data, fairly extensive editing was necessary and resulted in the exclusion of some observations because of unrealistic or missing values for one or more relevant variables. In order to maintain reasonable similarity between and among observations utilized in the regression analysis, those associated with the 9.7 percent of respondents not occupying their homes on a year-round basis were excluded.

Only four independent variables were used in the simple model: envelope volume (ENVVOL), central air conditioning (CEAC), number of occupants (NUMOCCS), and income (INC). Table 2 shows the estimated coefficients. Envelope volume had its smallest coefficients June through October, suggesting that other factors, like outside temperature, were more important determinants 
of consumption. The implied elasticities are shown in Table 3. A ten percent increase in volume increased KWH consumption about five percent from December through April.

The other results are consistent with previous studies. In the absence of actual outside temperature information, the existence of central air conditioning probably captures appliance ownership correlated with this variable. It is clearly most important in summer months, with December's coefficient possibly reflecting heat pump ownership. The role of occupants varies over the year -- affecting summer rather than winter KWH consumption. Finally, the implied income elasticities are also greatest in summer months, the seasonal peak period for this housing type.

These results indicate how monthly KWH consumption depends systematically on the volume to be heated or cooled, central air conditioning, family size, and income. Price was not found to be a significant determinant of consumption. Furthermore, these results do not capture a large number of other factors. These are investigated in a pooled model discussed below. 
Table 1

\section{Characteristics of Florida Manufactured Homes}

Age of Residence ( $31.5 \%$ are 1 to 6 years old)

Central air conditioning $(65.1 \%)$

Usual summer thermostat settings $(57.8 \%$ between 78 and 81$)$

Usual winter thermostat settings (39.8\% between 72 and 78 )

Age of compressor on the central air conditioner (24.5\% two years or less)

Primary source of heating (50.3\% electricity, $10.8 \%$ natural gas, $33.0 \%$ propane/bottled.

Use of Paddle Blade Ceiling Fans (62.4\%)

Color TV ownership (59.7\%)

Water well pump (25.9\%)

Number of residents ( $25.7 \%$ have one, $47.9 \%$ have two)

Ages and education levels of residents

Family income before taxes (36.8\% with $\$ 14,999$ or less)

Square footage ( $40.1 \%$ have $798 \mathrm{sq} \mathrm{ft}$ or less)

Insulation values of walls and attics

Quality of caulking and weatherstripping (59.5\% fair or poor)

Central Heat Pump (10.6\%)

Data are based on a FPSC sample of 688 mobile homes in Florida, 1986. 
Table 2

Basic Model: Monthly KWH Consumption

(t-statistics in parentheses)

$\begin{array}{llll}\text { Intercept } & \text { ENVVOL } & \text { CEAC } & \text { NUMOCCS } \\ \text { AdjR }^{2}\end{array}$

[Sample Size]

\begin{tabular}{|c|c|c|c|c|c|c|}
\hline March & $\begin{array}{c}38.5 \\
(0.60)\end{array}$ & $\begin{array}{c}0.031 \\
(3.09)\end{array}$ & $\begin{array}{c}.087 \\
(1.82)\end{array}$ & $\begin{array}{c}88.5 \\
(4.58)\end{array}$ & $\begin{array}{l}0.0022 \\
(1.27)\end{array}$ & $\begin{array}{r}.296 \\
{[178]}\end{array}$ \\
\hline April & $\begin{array}{c}30.7 \\
(0.69)\end{array}$ & $\begin{array}{l}0.036 \\
(5.70)\end{array}$ & $\begin{array}{c}.060 \\
(1.94)\end{array}$ & $\begin{array}{c}83.4 \\
(6.50)\end{array}$ & $\begin{array}{l}0.0024 \\
(2.12)\end{array}$ & $\begin{array}{r}.268 \\
{[398]}\end{array}$ \\
\hline May & $\begin{array}{c}37.5 \\
(0.59)\end{array}$ & $\begin{array}{l}0.033 \\
(3.71)\end{array}$ & $\begin{array}{c}.153 \\
(3.53)\end{array}$ & $\begin{array}{c}.109 \\
(5.93)\end{array}$ & $\begin{array}{l}0.005 \\
(3.64)\end{array}$ & $\begin{array}{r}.247 \\
{[433]}\end{array}$ \\
\hline June & $\begin{array}{c}.129 \\
(1.61)\end{array}$ & $\begin{array}{l}0.031 \\
(2.66)\end{array}$ & $\begin{array}{c}.270 \\
(4.81)\end{array}$ & $\begin{array}{c}.120 \\
(5.18)\end{array}$ & $\begin{array}{c}0.08 \\
(4.18)\end{array}$ & $\begin{array}{c}.246 \\
{[411]}\end{array}$ \\
\hline July & $\begin{array}{c}61.0 \\
(0.74)\end{array}$ & $\begin{array}{l}0.036 \\
(3.13)\end{array}$ & $\begin{array}{c}.230 \\
(4.09)\end{array}$ & $\begin{array}{c}.151 \\
(6.41)\end{array}$ & $\begin{array}{c}0.07 \\
(3.45)\end{array}$ & $\begin{array}{c}.244 \\
{[439]}\end{array}$ \\
\hline August & $\begin{array}{c}27.0 \\
(0.31)\end{array}$ & $\begin{array}{l}0.035 \\
(2.85)\end{array}$ & $\begin{array}{c}.260 \\
(4.32)\end{array}$ & $\begin{array}{c}.178 \\
(6.98)\end{array}$ & $\begin{array}{c}0.06 \\
(2.95)\end{array}$ & $\begin{array}{c}.239 \\
{[461]}\end{array}$ \\
\hline September & $\begin{array}{c}.122 \\
(1.62)\end{array}$ & $\begin{array}{c}0.01 \\
(1.82)\end{array}$ & $\begin{array}{c}.272 \\
(5.31)\end{array}$ & $\begin{array}{c}.134 \\
(6.35)\end{array}$ & $\begin{array}{c}0.07 \\
(4.22)\end{array}$ & $\begin{array}{c}.254 \\
{[419]}\end{array}$ \\
\hline October & $\begin{array}{c}80.0 \\
(1.28)\end{array}$ & $\begin{array}{c}0.03 \\
(3.70)\end{array}$ & $\begin{array}{c}.208 \\
(4.87)\end{array}$ & $\begin{array}{c}.100 \\
(5.64)\end{array}$ & $\begin{array}{c}0.06 \\
(4.19)\end{array}$ & $\begin{array}{c}.252 \\
{[462]}\end{array}$ \\
\hline November & $\begin{array}{c}46.5 \\
(0.94)\end{array}$ & $\begin{array}{c}0.03 \\
(4.28)\end{array}$ & $\begin{array}{c}.097 \\
(2.82)\end{array}$ & $\begin{array}{c}.106 \\
(7.50)\end{array}$ & $\begin{array}{c}0.00 \\
(3.49)\end{array}$ & $\begin{array}{c}.296 \\
{[417]}\end{array}$ \\
\hline December & $\begin{array}{c}69.0 \\
(1.04)\end{array}$ & $\begin{array}{c}0.05 \\
(5.63)\end{array}$ & $\begin{array}{c}.181 \\
(3.94)\end{array}$ & $\begin{array}{c}72.5 \\
(3.68)\end{array}$ & $\begin{array}{c}0.00 \\
(2.77)\end{array}$ & $\begin{array}{c}.260 \\
{[404]}\end{array}$ \\
\hline January & $\begin{array}{c}21.5 \\
(0.32)\end{array}$ & $\begin{array}{c}0.07 \\
(7.58)\end{array}$ & $\begin{array}{c}.144 \\
(3.20)\end{array}$ & $\begin{array}{c}60.0 \\
(3.08)\end{array}$ & $\begin{array}{c}0.05 \\
(3.24)\end{array}$ & $\begin{array}{c}.271 \\
{[465]}\end{array}$ \\
\hline February & $\begin{array}{c}83.5 \\
(1.53)\end{array}$ & $\begin{array}{c}0.04 \\
(6.07)\end{array}$ & $\begin{array}{c}.084 \\
(2.23)\end{array}$ & $\begin{array}{c}66.0 \\
(4.13)\end{array}$ & $\begin{array}{c}0.00 \\
(3.89)\end{array}$ & $\begin{array}{c}.268 \\
{[414]}\end{array}$ \\
\hline
\end{tabular}


Table 3

Implied Elasticities for the Simple Model

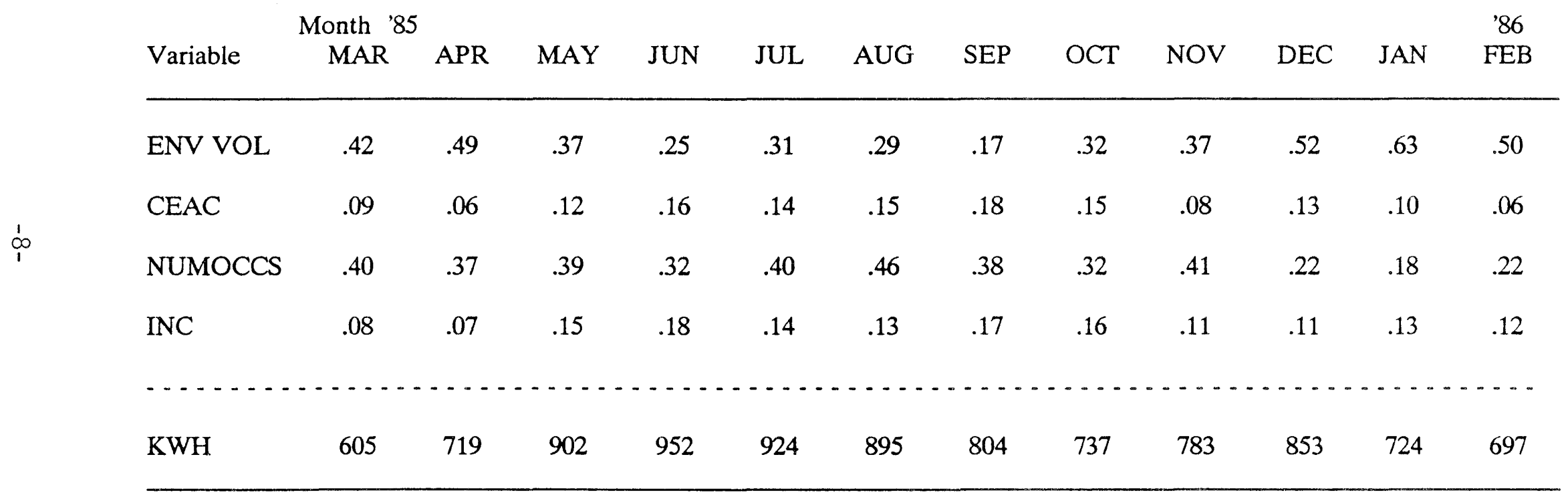




\subsection{A Pooled Model}

In order to reduce statistical problems caused by seasonal climatic variations and associated behavioral factors, the regression model was run using "pooled" monthly observations, i.e., there are twelve possible monthly KWH consumption figures associated with each household surveyed. The pooled model contains a number of variables with definitions and results presented below.

$$
\begin{aligned}
& \text { KWHMON }=\mathrm{b} 0+\mathrm{b} 1(\mathrm{RESAGE})+\mathrm{b} 2(\mathrm{PRMHTFUL})+\mathrm{b} 3(\mathrm{ENVVOL})+ \\
& \mathrm{b} 4(\text { WTRHTLOC })+\mathrm{b} 5(\mathrm{OWN})+\mathrm{b} 6(\mathrm{QUALWNSL})+\mathrm{b} 7(\text { NUMOCCS })+ \\
& \mathrm{b} 8(\mathrm{INC})+\mathrm{b} 9(\text { E_DRY })+\mathrm{b} 10(\text { WWPUMP })+\mathrm{b} 11(\text { EWTRHTR })+\mathrm{b} 12(\mathrm{CEAC})+ \\
& \mathrm{b} 13(\text { CHPAC })+b 14(\text { FAN })+b 15(\text { WALUSALL })+b 16(\text { THRMCOOL })+ \\
& \mathrm{b} 17(\mathrm{THRMHEAT})+\mathrm{b} 18(\mathrm{ANOR})+\mathrm{b} 19(\mathrm{ASOU})+\mathrm{b} 20(\mathrm{AEW})+ \\
& \mathrm{b} 21(\mathrm{ASESW})+\mathrm{b} 22(\mathrm{ANENW})+\mathrm{b} 23(\mathrm{MHDD})+\mathrm{b} 24(\mathrm{MCDD})+ \\
& \text { b25(AVGINS_A) + b26(AVGINS_W) + e }
\end{aligned}
$$

The dependent variable in the regression model is monthly $\mathrm{KWH}$ electricity consumption (KWHMON). Table 4 presents the estimated coefficients with the results interpreted below. 


\section{Table 4}

Comprehensive Model: Pooled Monthly KWH Consumption

\begin{tabular}{|c|c|c|c|c|}
\hline Variable & $\begin{array}{l}\text { Estimated } \\
\text { Coefficient }\end{array}$ & T-statistic & $\begin{array}{c}\text { Variable } \\
\text { Mean }\end{array}$ & $\begin{array}{l}\text { Implied } \\
\text { Elasticity }\end{array}$ \\
\hline INTERCEPT & -841.3 & -11.8 & & \\
\hline RESAGE & 123.9 & 5.4 & .661 & .10 \\
\hline PRMHTFUL & 141.8 & 6.5 & .469 & .08 \\
\hline ENVVOL & .012 & 2.3 & 7368 & .11 \\
\hline WTRHTLOC & -44.5 & -2.2 & .368 & -.02 \\
\hline OWN & 102.9 & 2.6 & .921 & .12 \\
\hline QUALWNSL & $-25.4^{*}$ & -1.1 & .462 & $-.015^{*}$ \\
\hline NUMOCCS & 130.2 & 14.0 & 2.39 & .39 \\
\hline INC & .006 & 8.3 & 17450 & .13 \\
\hline E_DRY & 164.5 & 7.1 & .582 & .12 \\
\hline WWPUMP & 164.5 & 7.2 & .259 & .05 \\
\hline EWTRHTR & 99.0 & 2.5 & .924 & .11 \\
\hline CEAC & 353.0 & 13.4 & .543 & .24 \\
\hline CHPAC & 255.1 & 5.6 & .065 & .02 \\
\hline FAN & $-4.8^{*}$ & -0.7 & 1.52 & $-.01^{*}$ \\
\hline WALUSALL & 326.0 & 9.7 & .112 & .05 \\
\hline THRMCOOL & 148.0 & 6.2 & .662 & .12 \\
\hline THRMHEAT & $-7.1^{*}$ & -0.4 & .385 & $-.003^{*}$ \\
\hline ANOR & -2.5 & -5.4 & 24 & -.07 \\
\hline ASOU & 3.4 & 5.9 & 20 & .08 \\
\hline AEW & 0.75 & 2.6 & 38 & .035 \\
\hline ASESW & 1.6 & 1.8 & 3.6 & .007 \\
\hline ANENW & -2.1 & -1.9 & 3.6 & -.009 \\
\hline MHDD & 0.97 & 8.5 & 62.81 & .08 \\
\hline MCDD & 0.76 & 11.3 & 289.05 & .27 \\
\hline AVGINS_A & $-2.2^{*}$ & -1.1 & 11.5 & $-.03^{*}$ \\
\hline AVGINS_W & 10.1 & 3.2 & 7.5 & .09 \\
\hline \multicolumn{5}{|l|}{ * Not significant } \\
\hline $\operatorname{adj} R^{2}=.426$ & & & & \\
\hline sample $=2164$ & & & & \\
\hline
\end{tabular}




\subsection{Housing and Income}

RESAGE is a qualitative variable which assigns the monthly observations for each manufactured housing unit to either an "older" (1) or relatively "newer" (0) group of homes. This variable is a proxy for low energy efficiency thermal envelope. We were unable to create a satisfactory explanatory continuous variable to capture the effect of insulation levels across the housing units in the study. Summary statistics reveal that insulation values were unavailable and could not be readily determined for a substantial number of housing units in the data set.

Since the earliest minimum insulation standards for the manufactured housing industry were imposed by the Department of Housing and Urban Development (HUD) effective June 15, 1976, we expected units manufactured prior to and after that date to have different characteristics. Since inventories of units completed before the effective date for the new standards and possible delays in compliance might have created a lag in the impact of the insulation rules on the stock of manufactured housing units, RESAGE is assigned a value of one if the age of the home is six years or more and zero otherwise. While the implicit two-year lag in the full effect of implementation of the HUD requirements is both reasonable and realistic, it is likely that this variable is also capturing effects related to improvements in design, materials, construction techniques and appliance efficiency in addition to higher insulation values. The coefficient of 123.9 implies that, controlling for other factors, manufactured homes purchased before 1979 consume, on average, 15.3 percent more KWHs of electricity than the relatively newer group of homes. About two-third of the homes fell in the "old" category.

PRMHTFUL is a qualitative variable intended to capture the difference in $\mathrm{KWH}$ consumption between manufactured homes using electricity as the primary fuel for heating (1) and those utilizing one or more alternative energy sources for heating purposes (0). As anticipated, there is a strong positive (significant) relationship between this variable and electricity usage. This result 
of 141.8 can be viewed as an "average" effect of short, intense "bursts" of consumption during the cold spells characteristic of Florida's winter weather (see THRMCOOL and THRMHEAT). About 47 percent of the sample units heat with electricity, with the remainder opting for an alternative fuel.

ENVVOL, also included in the basic model, measures the impact of the total volume of the conditioned thermal envelope (in cubic feet) on KWH consumption. This variable has been adopted in lieu of the traditional "square footage of living area" variable because $36 \%$ of the mobile homes in this study have a seven foot ceiling, while the remaining have an eight-foot ceiling height. We feel that the volume measure more accurately represents the "size" of the residence. The parameter estimate implies a one kilowatt-hour per month increase in consumption for each 100 cubic feet of additional conditioned space.

WTRHTLOC, a qualitative independent variable, tests the influence of the location of the water heater: within or outside of the conditioned thermal envelope. Although variables testing the efficacy of insulating blankets and tank insulation upgrades proved insignificant in this study, variables for the use of electricity to heat water (EWTRHTR) and the location variable were found to be significant contributors to KWH consumption in manufactured houses.

Two primary considerations led to the development of this variable: (1) the fact that water heater location was an issue in early versions of the Florida Energy Efficiency Code for Building Construction and (2) the probability that, in order to be cost effective, placement of the water heater must be decided during the design phase of the manufacturing process. The construction code for site-built homes now emphasizes heat recovery devices for the central air conditioner and flow restrictors on shower heads as the key means for conserving energy devoted to heating water. However, the water heater location in manufactured homes also a determinant of KWH consumption. WTRHTLOC is assigned a value of one for observations indicating the water heater is located in the conditioned space and a value of zero is assigned otherwise. The estimated coefficient of -45 implies 
that monthly $\mathrm{KWH}$ consumption is $45 \mathrm{KWH}$ less than for units with outside water heaters, a 6 percent reduction for the average monthly observation.

The frequency distribution for WTRHTLOC by RESAGE, the qualitative age variable, shows 40.7 percent of the older observations with water heaters located in the conditioned space compared with 29.25 percent of the newer group. Overall, 36.81 percent of the units had water heaters so located. Cross checking the frequency distribution by a continuous age variable confirmed the existence of a recent trend toward locating the water heaters outside the conditioned space. Examining the percentages of homes with water heaters located in the conditioned space by five year age increments yields the following result:

\section{AGE IN YEARS}

$1-5$

$6-10$

$11-15$

$16-20$

\section{PERCENT IN CONDITIONED SPACE}

39.7

61.7

66.4

59.2

This finding suggests that further investigation into the energy conservation potential of water heater location is warranted.

OWN is a qualitative variable developed to test for a relationship between home ownership and $\mathrm{KWH}$ consumption. As specified in the regression model, OWN is assigned a value of one if the respondents indicated either making mortgage payments or outright ownership. If the occupants are renting or occupying the home rent free, OWN takes on a value of zero. It was expected that ownership would be related to expectations of long term occupancy and, thus, encourage energy conserving investments such as additional insulation and more efficient heating, ventilation and air conditioning (HVAC) equipment and appliances.

Our regression results, however, indicated a positive relationship between ownership and 
electricity usage. This result indicates that the occupants of units who own their homes consume approximately 13 percent more each month than those renting or living rent-free. Given the large retirement component of the population, ownership may reflect a wealth effect which is independent of the role played by income.

QUALWNSL is a qualitative variable intended to capture the effect of variation in the condition of caulking or other type of physical seal around windows. The specification for this variable assigns a value of one if the interviewer determined that the seal around the window to be "good" and a value of zero if "fair" or "poor". This variable was included in the model in response to the consistent emphasis on window "tightness" and weather stripping in various energy conservation programs and building construction standards. The regression result on this variable, though not significant, showed the expected negative relationship between window seals which effectively prevent infiltration and KWH consumption. Lack of significance may be due to the short duration of cold spells and the low average wind velocities for both winter and summer. Future work should consider interacting this term with humidity and temperature variables. The frequency distribution for this variable shows 46.2 percent of the observations rated as good and 53.8 percent fair or poor.

NUMOCCS is a continuous variable based on the number of persons living in each manufactured home surveyed. As expected, the number of occupants associated with a given observation is strongly and positively related to KWH consumption levels. The estimated coefficient implies a 16 percent increase in electricity usage for each additional person residing in these housing units. The frequency distribution for this variable shows 100 percent of the observations with six or fewer occupants and 94.3 percent with four or less. The largest numbers of observations have either one or two residents, with frequencies of 20.8 and 46.4 percent respectively. It is likely that NUMOCCS captures a host of behavioral effects which are nearly impossible to isolate in a study of this nature: the number of laundry loads, the number and size of meals cooked, refrigerator use and 
heated water volumes for laundry, bathing and dish washing, to mention a few.

INC is a variable based on thirteen income ranges from which respondents in the survey were asked to specify one as representative of their families's total annual incomes. Each income range represents a $\$ 5,000$ increment in total annual income from less than $\$ 5,000$ to over $\$ 65,000$. INC is assigned the mean of each income range indicated by the respondents. Manufactured housing units in our regression analysis use an additional KWH of electricity for each \$166 increase in annual income. The frequency distribution for INC shows 90 percent of the observations with incomes under $\$ 35,000$ and the largest single category (17.2 percent), in the $\$ 10,000$ to $\$ 15,000$ range. Thus, our average income "family" with a mean income of $\$ 17,450$ consumes nearly $30 \mathrm{KWH}$ more per month than the median "family" earning $\$ 12,500$ per year. This variable probably captures a number of behavioral effects related to variations in income, including the number and size of appliances.

\subsection{The Appliance Variables}

In general, the appliance variables are dichotomous and are specified in the regression model as the number of each type present in a given unit according to respondents to the survey unless otherwise noted. For convenience, HVAC equipment is included with the appliance variables and, in fact, these machines operate on the same principles as other major appliances, although on a larger scale. For comparison purposes, the appliances discussed are listed in descending order by KWH consumption coefficient. Some appliances, such as personal computers, which looked significant in early tests were excluded because they were obviously picking up income or other effects not related to their intrinsic electricity consumption characteristics. Still others simply failed to show any significance in terms of explaining variations in $\mathrm{KWH}$ electricity consumption. All of the appliance variables included in the regression model demonstrate a positive relationship with monthly $\mathrm{KWH}$ consumption of electrical power and all but one are statistically significant.

CEAC, central electric air conditioning, has the largest estimated coefficient: the presence of 
an electrically powered central air conditioning unit is responsible, on average, for approximately 44 percent of monthly KWH electricity consumption. This result agrees closely with the findings published in Florida Power and Light Company's (FPL) 1986 Residential Heating and Cooling Study - Central Heating and Cooling System Load Contribution (June 1987). The data for mobile homes with central HVAC are listed by month and indicate an average 40.3 percent of monthly KWH consumption directly attributed to central HVAC equipment. The FPL study spans the year June, 1985 to May, 1986 compared to our study period March, 1985 to February, 1986. There are also substantial locational differences in the observations comprising the two study groups. The more rigorous demand load monitoring methodology utilized in the FPL study provides additional support for our result with this variable. Note that 54.3 percent of our subject observations utilize central electric air conditioning units and 31.3 percent cool and heat their homes with central HVAC equipment.

WALUSALL is a variable intended to capture the impact on monthly KWH consumption of the use of window or wall-type air conditioners to cool "most of the house." 11.2 percent of the observations in our study fall into this group. The estimated coefficient on this variable, 325.9 , is similar to that for CEAC. It is difficult to make any clear interpretation about this variable due to the potential for a number of extraneous influences. Size of the home, comfort levels, placement of the units, efficiency ratings, sizing considerations and maintenance practices can all modify the nature of the performance of these units. In general, this result is consistent with the established role of cooling equipment as the dominant consumer of residential electricity in Florida homes.

CHPAC is a variable intended to measure the effect of central electric heat pump-type HVAC equipment on monthly KWH electricity consumption. The inclusion of this variable in the model was prompted by the considerable debate as to whether the additional capital outlay for these units is cost effective for Florida consumers. The estimated coefficient on CHPAC is 255.13: a 28 percent 
reduction in monthly $\mathrm{KWH}$ consumption relative to the central electric $\mathrm{AC}$ units not employing heat pump technology. However, the fact that only 6.5 percent of the observations are associated with this equipment type prevents our making any generalizations based on this study.

E_DRY is a variable intended to capture the impact of electric clothes dryers on the dependent variable. This appliance is well represented in the data set, being associated with 58.2 percent of the observations. The estimated coefficient on this variable is 164.5 , implying 20.3 percent higher consumption levels than homes without this appliance. The consumption effect of these machines is complicated, since the ownership of clothes dryers and frequency of use are positively related to family size. Indeed, two-member households display a more than two-fold increase in percentage ownership over single member households and incrementally larger households are increasingly likely to own an electric clothes dryer. Thus, electricity consumption attributed to clothes dryers is driven by family size and related domestic and occupational behavior patterns.

WWPUMP is a variable measuring the impact of water well pumps on the magnitude of the dependent variable. Again, use should increase with family size. Overall, 25.9 percent of the observations in the data set include water well pumps in their appliance bundle. The estimated coefficient on WWPUMP is 164.5 , so ownership increases consumption 20.3 percent, on average.

EWTRHTR is the variable employed in our regression model to test for the impact of electric water heaters on monthly KWH electricity consumption. The frequency distribution for EWTRHTR shows that 92.4 percent of the observations use electricity for water heating. The estimated coefficient on this variable is 99 . The implied 12.2 percent increase in average monthly $\mathrm{KWH}$ consumption for homes with electric water heaters is of a reasonable magnitude. As is the case with all the appliance variables, behavioral factors for individual homes strongly influence the effect of water heating equipment on electricity usage. Separate variables for water temperature, insulating blankets and upgraded tank insulation were tested, but failed to show significance in our regressions. 
FAN is the variable included to assess the impact on $\mathrm{KWH}$ consumption of the use of ceiling fans by occupants of manufactured housing units. 63.4 percent of the observations in the data set indicated use of one or more paddle blade ceiling fans. The estimated coefficient on FAN is -4.78 , but is insignificant. The FAN variable was negatively related to the dependent variable and significant in several months when twelve separate monthly models were estimated. If, in fact, use of ceiling fans allows individuals to achieve a given perceived comfort level at a higher thermostat setting or without air conditioning in mild weather, this effect is negated by factors which we are unable to isolate from the available data.

\subsection{The Thermostat Setting Variables}

Two qualitative variables, THRMCOOL and THRMHEAT were created to test for the effect of variation in thermostat settings on monthly $\mathrm{KWH}$ consumption of electric power.

The specification for THRMCOOL, the variable based on thermostat settings "during a typical summer weekday," assigns a value of one for observations indicating a setting of 78 degrees $\mathrm{F}$. or lower and a value of zero for 79 degrees or above. THRMCOOL behaved as anticipated with a positive estimated coefficient of 147.9. This result implies that, as a group, the households represented in our study whose typical summer thermostat setting is below 79 degrees each consume an additional $148 \mathrm{KWHs}$ of electricity per month above the consumption level of the average household: an 18.3 percent increase in monthly consumption of electricity. The observations in our data set had a minimum value of 70 degrees, a maximum value of 90 degrees and a mean value of 79.3 degrees.

As specified in the regression model, THRMHEAT assigns a value of one to observations indicating a thermostat setting "during a typical winter weekday" of 71 degrees F. or higher and a value of zero otherwise. In the regression analysis, THRMHEAT had an estimated coefficient of 7.1, but was insignificant. More careful modeling of meteorological conditions is called for here, since 
heating demands tend to be driven by short cold spells.

\subsection{The Orientation Variables}

Of special interest to this study is the analysis of window orientation and related information available from this unique data set. This interest is inspired by the potential for flexibility in siting of manufactured homes, especially in rural areas, and the emphasis on subsidizing residential solar film applications by at least one Florida electric utility company. Up to eight window groups are recorded for each domicile surveyed, with window type, area, orientation, shading, insulation and overhang projection coded for each group. From the available data, six variables were created to capture variation in the effect of solar radiation on monthly $\mathrm{KWH}$ electricity consumption due to changes in directional orientation. Due to the tilt of the Earth's rotational axis relative to the sun, the angles at which solar rays strike surfaces of similar vertical orientation are symmetrical about the north-south plane. ${ }^{1}$ Therefore, in terms of solar heat gain through fixed vertical glazed fenestrations, only five variables are required to represent the eight directions quartering the compass: (1) ANOR represents the adjusted window area facing north, (2) ASOU is the adjusted sum of the south-facing window areas, (3) AEW is the combined total for east and west-facing windows, (4) ASESW for windows facing southeast or southwest and (5) ANENW for windows facing northeast or northwest. Since none of the manufactured home observations in the study had a skylight, the variable for horizontal window areas could be excluded. The adjustment process alluded to in the introduction of the variables is an attempt to account for the effect of known shading factors. The presence of window awnings, solar film and overhangs of various length are detailed in the data set and have been taken into account in the adjusted areas utilized in the regression.

\footnotetext{
${ }^{1}$ This phenomenon accounts for the relatively smaller number of daylight hours in winter than in summer. Specifically, the sun rises nearly due east and sets neariy due west at the summer solstice (June 21) while tracing an arc high across the sky, while at the winter solstice (Dec 21) the sun rises and sets some $15^{\circ}$ south of east and west, respectively, and traces a relatively lower arc across the sky. We have relied on standard engineering tables for the appropriate latitude which take into account the seasonal variation in the sun's path across the southern sky.
} 
The estimated coefficients on the orientation variables are as follows:

\begin{tabular}{|c|c|c|c|}
\hline VARIABLE & COEFFICIENT & T-STATISTIC & CONFIDENCE LEVEL \\
\hline ANOR & -2.5 & -5.388 & .0001 \\
\hline ASOU & 3.4 & 5.923 & .0001 \\
\hline AEW & 0.8 & 2.636 & .008 \\
\hline ASESW & 1.6 & 1.817 & .069 \\
\hline ANENW & -2.1 & -1.929 & .054 \\
\hline
\end{tabular}

Since the coefficient estimates are interpreted as the monthly KWH impact on electricity consumption per square foot of window area, the percentage impact on average KWH consumption for units in the study is calculated by multiplying the estimated coefficient for each variable by the mean area value for that variable and dividing by the mean value for the dependent variable. The results in table form:

\begin{tabular}{|c|c|c|}
\hline$\underline{\text { VARIABLE }}$ & MEAN SQ FT AREA & IMPACT ON MONTHLY KWH CONSUMPTION \\
\hline ANOR & 24 & 7.4\% REDUCTION \\
\hline ASOU & 20 & 8.4\% INCREASE \\
\hline AEW & 38 & $3.8 \%$ INCREASE \\
\hline ASESW & 4 & ------ \\
\hline ANENW & 4 & -..-.---.--- \\
\hline
\end{tabular}

While the areas associated with the ASESW and ANENW variables are so small as to preclude their significance, the overall results are certainly non-trivial. The data available to us are surely affected by extraneous influences such as shade from trees, shrubs and adjacent structures as well as behavioral factors which resist quantification. It should be noted also that solar heat loading cuts both ways, i.e., the heat gain we seek to exclude in summer months may be a welcome warming 
influence in cold weather. On net, our results confirm the potential for cost effective window-related conservation efforts and the need for further investigation into the practicality of site orientation conservation strategies.

\subsection{The Degree Day Variables}

MHDD and MCDD are continuous variables created to test for the effect of ambient air temperature on the dependent consumption variable. The measure of temperature utilized in our study is based, in a somewhat stylized way, on the notion that heating equipment will be activated if the daily mean temperature is below 65 degrees $F$., in which case one heating degree day is accumulated for each degree the mean temperature falls below that level. Similarly, one cooling degree day is accumulated for each degree above 65 degrees $F$. the mean temperature happens to be for a given day. Heating and cooling degree days are expressed as monthly totals for various reporting stations in bulletins published by the National Oceanographic and Atmospheric Administration (NOAA). As specified in the regression model, the degree day numbers reported by the station(s) in each county have been averaged to produce a single mean degree day figure for heating and cooling for each of the 67 Florida counties. Thus, MHDD and MCDD represent relative degrees of cold or hot weather, respectively, for the particular Florida county where an observation is located.

The estimated coefficient on MCDD is .763 . The mean monthly cooling degree day figure across all counties is 289 . Thus, our result implies that each cooling degree day at a given location increases monthly KWH consumption by just over three quarters of one KWH which totals to an average monthly increase of 27.3 percent based on cooling degree days. The estimated coefficient on MHDD is .972 . Interpretation similar to that for MCDD implies an average monthly increase in KWH consumption due to heating degree days of 7.5 percent. This confirms the transitory nature of cold weather in Florida and is consistent with the relatively greater duration of electricity use 
during the "cooling" season. Ironically, it is the intense bursts of demand associated with unusually cold nights that can overwhelm the Florida electric utility's peak generating capacities.

\subsection{The Insulation Variables}

AVGINS_A and AVGINS_W are continuous variables intended to measure the effects on KWH consumption of attic and wall insulation levels, respectively. As mentioned in the discussion of the RESAGE variable, the response to the query concerning average insulation values for the attic and walls was quite weak, but understandably so. Given the lack of concern over such matters in past decades, coupled with the large number of relatively older manufactured homes in the housing stock and the fact that it is practically impossible to evaluate the amount or condition of insulation without disassembling the structure, it is not surprising that "DON'T KNOW" was the response 35.9 percent of the time for wall insulation and 48.1 percent of the time for ceiling insulation.

Contrary to expectations, the estimated coefficient on AVGINS_A, a value of -2.15 , is not significant. The coefficient on AVGINS_W, a value of 10.05 , though significant, is not of the expected sign. This result may be indicative of a "cost of comfort" effect, whereby occupants of better insulated manufactured homes make a rational decision to indulge in a higher level of comfort due to the perceived reduction in cost of achieving additional comfort.

\section{ENERGY POLICY IMPLICATIONS}

The empirical results suggest that insulation levels (for which age of the house served as the proxy) are important determinants of electricity consumption. Similarly, location of the hot water heater within the thermal envelope reduced KWH consumption 6 percent. Of course, space is at a premium, so the value of an additional closet or storage area may outweight the energy costs of the external location. However, home buyers are probably not aware of the full consequences of location decisions. Attention to housing orientation can also yield savings--although the benefits of scenic 
vistas can quickly outweigh the small penalties from positioning a manufactured house particular ways.

One must ask why investments with relatively short payback periods are not undertaken. In this industry, there is a vertical chain from home manufacturers to retailers to park managers. Potential homeowners generally deal with retailers, so the key issues involve consumer information regarding energy-saving options (See Stern, 1986). Consumers certainly ought to motivated to reduce the cost of living in a manufactured home--monthly payments for the lot, the house, and energy. The latter can run well over one-hundred dollars per month in Florida--where substantial cooling and heating demands occur, depending on the season. Retailers are in a position to provide information. However, unlike the case of appliance energy efficiency, the factors affecting a manufactured home's energy efficiency are complex and difficult to communication. ${ }^{2}$ In addition, targeted incentive programs can be cost effective for electric utilities.

We hope that these new empirical results stimulate further examination of factors affecting KWH consumption. The signs and sizes of various coefficients are generally consistent with those predicted by economic theory. The results for external hot water heaters, site orientation (and window space) and housing age suggest that there is much room for increased energy efficiency for this component of the residential sector.

\footnotetext{
2 In a separate project, we surveyed dealers' attitudes towards energy conservation. The local telephone book provided dealers addresses. Over half the questionnaires were returned as "addressee relocated-leaving no forwarding address." The industry appears to be fragmented, with substantial entry and exit activity.
} 


\section{REFERENCES}

Capehart, Barney L., Anthony B. Bridgwater, and John D. Steedly, "Energy Efficiency Incentive Standards for Manufactured Homes: A Preliminary Study," University of Florida Working Paper, 1990.

Capper, G., and A. Scott, "The Economics of House Heating: Further Findings," Energy Economics, April 1982, 134-138.

EPRI 1984, "Survey of Conditional Energy Demand Models for Estimating Residential Unit Energy Consumption Coefficients."

EPRI EA-3410, prepared by Angel Economic Reports and Applied Econometrics, Inc., February 1984.

EPRI 1988, Frederick Sebold and Kenneth L. Parvis, "Survey of Conditional Demand Estimates of Residential Unit Energy Consumption," September 1988.

Hirst, E., R. Goeltz, and J. Carney, "Analysis of Disaggregate Data," Energy Economics, April 1982, 74-82.

Garbacz, C., "A Model of Residential Demand for Electricity Using a National Household Sample," Energy Economics, April 1983, 124-128.

Kushman, J. E., and J. G. Anderson, "A Model of Individual Household Temperature Demand and Energy-Related Welfare Changes Using Satiety," Energy Economics, July 1986, 174154.

Parti, C. and M. Parti, "The Total and Appliance-Specific Conditional Demand for Electricity in the Household Sector," Bell Journal of Economics, Spring 1980.

Reilly, J. M., and S. A. Shankle, "Auxiliary Heating in the Residential Sector," Energy Economics, January 1988, 29-41.

Stern, P., "Blind Spots in Policy Analysis: What Economics Doesn't Say About Energy Use," Journal of Policy Analysis and Management, Winter 1986, r, No. 2, pp. 200-227. 